\title{
A novel serine hydroxymethyltransferase from Arthrobacter nicotianae: characterization and improving catalytic efficiency by rational design
}

Wei Jiang ${ }^{1}$, Lin Chen ${ }^{1}$, Nan Hư ${ }^{2}$ Shaohui Yuan ${ }^{1}$, Bin Li ${ }^{1}$ and Ziduo Liư ${ }^{1 *}$

\begin{abstract}
Background: Serine hydroxymethyltransferase (SHMT) is the key enzyme in L-serine enzymatic production, suggesting the importance of obtaining a SHMT with high activity.

Results: Here, a novel SHMT gene, glyA, was obtained through degenerate oligonucleotide-primed PCR and encoded a novel SHMT with 54.3\% similarity to the known SHMT from Escherichia coli. The obtained protein AnSHMT showed the optimal activity at $40^{\circ} \mathrm{C}$ and $\mathrm{pH} 7.5$, and was more stable in weakly alkali conditions (pH 6.5-8.5) than Hyphomicrobium methylovorum's SHMT (pH 6.0-7.5), In order to improve the catalytic efficiency of the wild type, the site-directed mutagenesis based on sequences alignment and bioinformatics prediction, was used and the catalytic efficiency of the mutant 1249L was found to be 2.78-fold higher than that of the wild-type, with the replacement of isoleucine by leucine at the 249 position.
\end{abstract}

Conclusions: This research provides useful information about the interesting site, and the application of DOP-PCR in cloning a novel glyA gene.

Keywords: Arthrobacter nicotianae, SHMT, Characterization, Site-directed mutagenesis, Catalytic efficiency

\section{Background}

There have been only a few reports about the enzymatic characterization and the change of the enzymatic properties of SHMT by protein engineering [1,2]. Currently, L-serine production mainly relies on enzymatic conversion from glycine precursor plus a $C_{1}$ compound [3], and the key enzyme in L-serine enzymatic conversion is SHMT. The SHMT is coded by the glyA genes and act as the first enzyme in the assimilation of $\mathrm{C}_{1}$ compounds through the addition of formaldehyde to glycine, producing the principal intermediate in the pathway, serine [4]. Therefore, it is necessary to obtain a SHMT with high activity of some new microorganisms and improve the catalytic efficiency through in vitro directed evolution.

SHMT (EC 2.1.2.1), a member of the $\alpha$-class of pyridoxal phosphate enzymes, catalyzes the reversible interconversion of serine and glycine, changes the chemical

\footnotetext{
* Correspondence: Izd@mail.hzau.edu.cn

'State Key Laboratory of Agricultural Microbiology, College of Life Science and Technology, Huazhong Agricultural University, Wuhan 430070, P. R. China

Full list of author information is available at the end of the article
}

bonding at the $C^{\alpha}-C^{\beta}$ bond of the serine side-chain mediated by the pyridoxal phosphate cofactor [5]. The crystal structures of SHMT from the human and rabbit confirm that SHMT belongs to the $\alpha$-family of enzymes and shares a similar tertiary fold and mechanism [6,7]. SHMT is ubiquitous, highly conserved PLP-dependent enzyme with tetrahydrofolate (THFA) as the $C_{1}$ acceptor [8], purified from the animals $[9,10]$, plants [11] and bacteria [12]. SHMT is widely used in the synthesis of the serine using glycine and formaldehyde, while the activity of the wild-type is not sufficient for industrial production [2].

The degenerate oligonucleotide-primed PCR (DOPPCR) has been applied to the characterization of abnormal chromosomes and also in the cloning of new markers for specific chromosome regions [13]. Based on unknown genome information circumstances, using DOP-PCR to obtain glyA (encoding SHMT) can overcome the shortcomings of existing methods, such as cDNA library $[14,15]$, southernblot hybridization [16], direct PCR amplification according to the known genome information $[17,18]$, and shotgun technology [19], for their waste time and material under the same conditions. Protein engineers redesign proteins in 
order to improve their biomedical or industrial utility [20]. Although the crystal structures of SHMT from the human, rabbit and Escherichia coli (E. coli) are reported, little is known at present about the structure-function relationship among these enzymes [5-7]. And the exact active-site residues have never been confirmed using kinetic analyses of the wild-type and variant enzymes. Structure-based sitedirected mutagenesis is usually applied to produce variants with dramatically improved specificities and the residues in or near the active site tend to be chosen as their special roles in the activity of the enzymes [21-23].

The objectives of the current study were to (i) clone the glyA gene from Arthrobacter nicotianae (A. nicotianae) using degenerate primers, (ii) study characteristics of recombinant SHMT by isolating the enzyme with high activity and (iii) improve its catalytic efficiency by site-directed mutagenesis.

\section{Results}

\section{Cloning of glyA gene}

Using degenerate primers, a fragment was obtained by DOP-PCR with the genomic DNA of A. nicotianae as the template. The open reading frame (ORF) of the gly $A$ (1323 bp, GenBank: KF359496) fragment encoded a polypeptide of 440 amino acids, with a deduced molecular mass of $47.3 \mathrm{kDa}$. The phylogenetic analyses of the SHMT sequences produced a tree to further verify the evolutionary relationship among AnSHMT and other known SHMTs, indicating that the AnSHMT shared 54.3\% amino acid identity with the known SHMT from E. coli (Figure 1).

\section{Bioinformatic analysis of the amino acid sequence}

Multiple sequence comparisons were performed by Clustal W Method, indicating that the conserved amino acid sequences and motifs are critical for the active site of SHMT (Figure 2). The highly conserved active site in all known SHMT enzymes T/ST/STTHKT/SL was also found in AnSHMT (235-242) in the form of TSTTHKTL (Figure 2c), the putative active site [5,14,24]. The site of the site-directed mutagenesis underlined and marked by a five-pointed star was the close proximity to the highly conserved active site and the putative active site (TSTTHKTL) (Figure 2c). The deduced active site structure (TSTTHKTL) and the position of the mutant (249 isoleucine) were briefly presented the three-dimensional structure of AnSHMT (Figure 3).

Based on multiple sequence comparisons, two wellknown conserved sequences LTNKYAEGYPGRRYYGG (61-77) and GGHLTHG (134-140) (Figure 2a and 2b) were also detected in AnSHMT [25]. The glycine rich region GQQGGP (268-273) (Figure 2c), was highly conserved sequence, significant homologous sequence, and proposed to be essential for PLP binding [24], the region of which was indicated on the three-dimensional structure of AnSHMT (Figure 3).

\section{Site-directed mutagenesis}

A leucine residue was introduced into the 249 position using site-directed mutagenesis and conformed, followed by the test of its effects on enzymatic activity using purification I249L-SHMT.

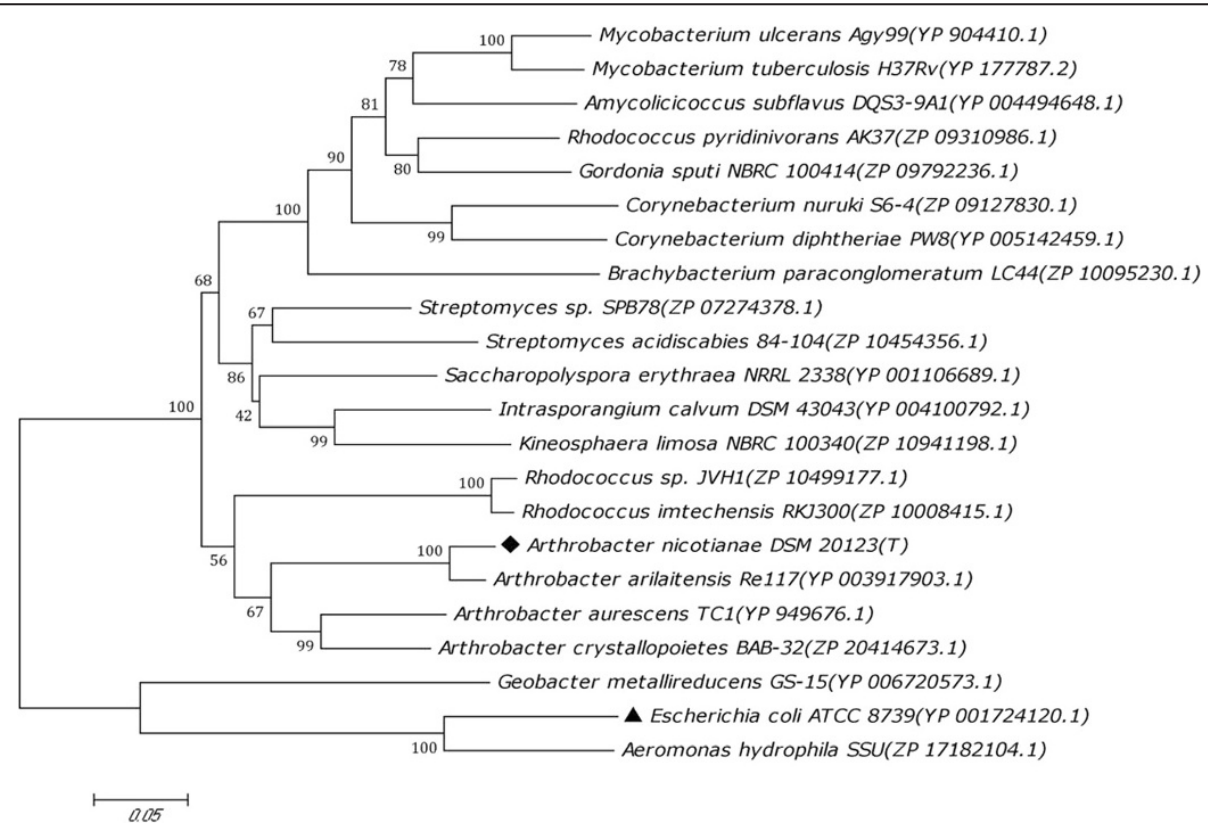

Figure 1 Phylogenetic tree of the AnSHMT. The phylogenetic tree was established using the program MEGA 5.05. The SHMT protein sequences were obtained from GenBank and PDB (http://www.rcsb.org/pdb/home/home.do), except for AnSHMT. 
(a)

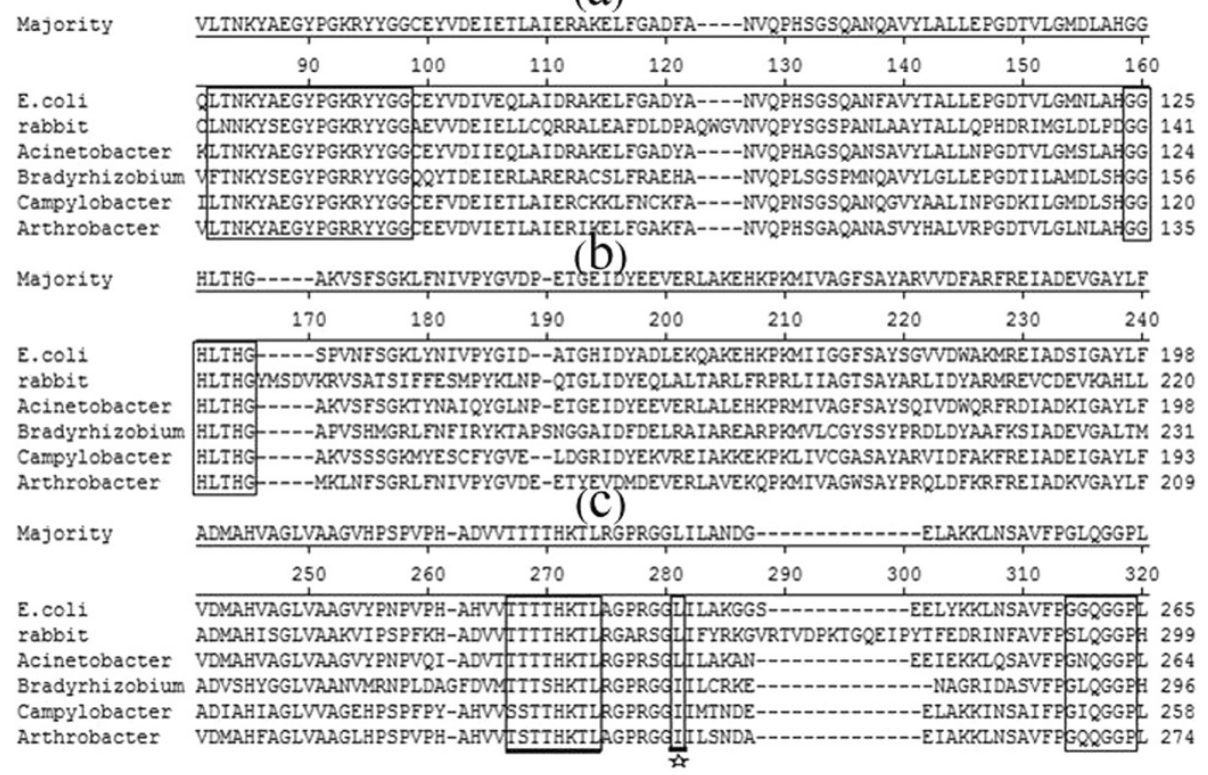

Figure 2 Multiple sequence comparison by ClustalW. (a) a part of the sequence alignment result (81-160 sites); (b) a part of the sequence alignment result (161-240 sites); (c) a part of the sequence alignment result (241-320 sites). Open boxes indicate the four highly conserved regions and the conserved active site is underlined. The site-directed mutagenesis site is underlined and is marked by five-pointed star. The amino acid sequences were obtained from NCBI database (http://www.ncbi.nlm.nih.gov/).

\section{Expression, purification and activity of the AnSHMT and} the mutant

The $g l y A$ was cloned into the vector pGEX-6p-1 and expressed in DE3. The induced and non-induced recombinant bacteria (harboring pGEX-6p-glyA) and the induced control bacterium (harboring empty pGEX-6p-1 vector) were examined with SDS-PAGE (Figure 4c). After purification with Glutathione Sepharose $4 \mathrm{~B}$ and digestion with $3 \mathrm{C}$ protease, the recombinant $A n S H M T$ and I249L-SHMT were harvested and resolved to a single band, with the purified AnSHMT exhibiting the expected molecular mass (47.3 kDa) (Figure 4c).

The steady-state kinetic parameters of the wild-type enzyme and the I249L-SHMT were measured at $40^{\circ} \mathrm{C}$ at a DL-3-phenylserine concentration from $0.1-16.3 \mathrm{mg} / \mathrm{ml}$ (Table 1). Mutant I249L showed a 7\% increase in $\mathrm{Km}$ and 2.97-fold increase in $k_{c a t}$, resulting in approximately 2.78 fold increase in $\left(k_{c a t} / K m\right)$. The results indicated that the

\section{(a)}

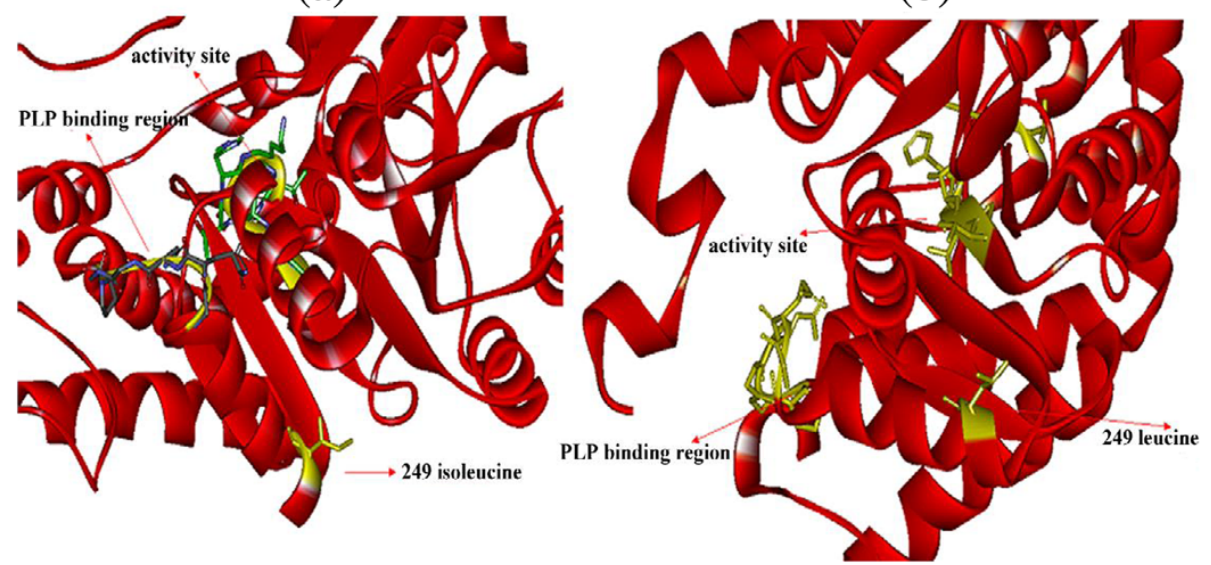

Figure 3 Modeled three-dimensional structure of the AnSHMT. (a) the three-dimensional structure of the wild type enzyme; (b) the three-dimensional structure of the mutational enzyme. The catalytic site, PLP binding region and the site of site-directed mutagenesis were indicated on the three-dimensional structure, respectively. The three-dimensional structure was generated using the Swiss-Pdb viewer. 
(a)

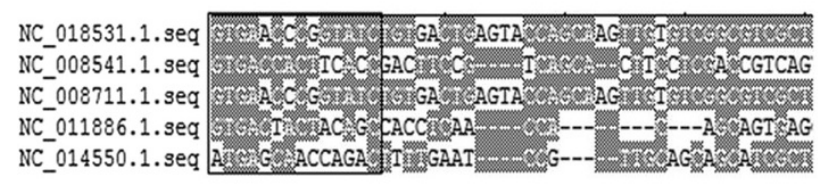

(b)

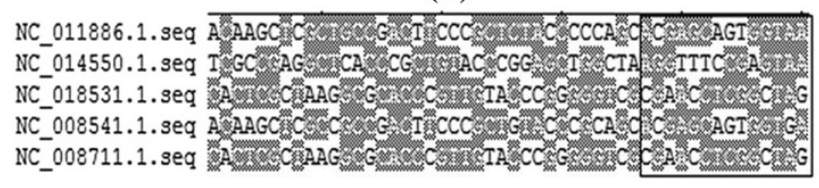

(c)

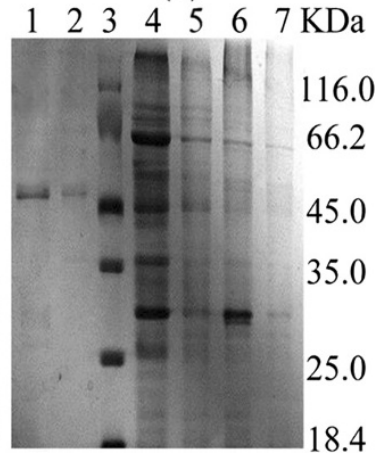

Figure 4 Design of both end degenerate primers and 12\% SDS-PAGE analysis of the purified proteins. (a and b) The glyA gene sequences were obtained from NCBI database and belonged to the genus of Arthrobacter (Gl: NC_008541; NC_008711.1; NC_01 1886.1; NC_014550.1; NC_018531.1). Degenerate primers were designed by the regions in the boxes. (c) 12\% SDS-PAGE analysis of the purified proteins. The bands in the ellipses show GST (glutathione-S-transferase) and fusion protein (AnSHMT and GST) respectively. Lane 1: purified I249L without GST. Lane 2: purified AnSHMT (the wild-type enzyme) without GST. Lane 3: protein marker. Lane 4: recombinant bacterium (harboring pGEX-6P-glyA) induced by IPTG. Lane 5: recombinant bacterium (harboring pGEX-6P-glyA) non-induced by $0.1 \mathrm{mM}$ IPTG. Lane 6: bacterium (harboring pGEX-6p-1) induced by IPTG. Lane 7: bacterium (harboring pGEX-6p-1) non-induced by 0.1 mM IPTG. The protein molecular weight ladder is Unstained Protein Molecular Weight Marker (Fermentas, Canada).

catalytic efficiency was considerably improved by replacing the isoleucine with leucine at the 249 position.

\section{Effects of temperature and $\mathrm{pH}$ on enzyme activity}

The maximal activity of the AnSHMT was observed at $40^{\circ} \mathrm{C}$, retaining over $50 \%$ of the maximal activity at temperatures from $30^{\circ} \mathrm{C}$ to $65^{\circ} \mathrm{C}$ (Figure 5a). The I249LSHMT diaplayed the same optimum temperature $\left(40^{\circ} \mathrm{C}\right)$ with the AnSHMT (Figure 5a). After $1 \mathrm{~h}$ incubation under $\mathrm{pH} 7.5$ (Figure 5c), the AnSHMT retained over $35 \%$ of its maximal activity from $35^{\circ} \mathrm{C}$ to $45^{\circ} \mathrm{C}$, but less than $15 \%$ at $55^{\circ} \mathrm{C}$.

The AnSHMT exhibited the optimal activity at $\mathrm{pH} 7.5$, and was sensitive in low $\mathrm{pH}$ buffers, displaying less than $20 \%$ of its maximal activity at pH 5.5 and nearly no activity was detected below pH 2.5 (Figure 5b). Similarly, the I249L-SHMT also showed the maximal activity at $\mathrm{pH} 7.5$, and retained over $85 \%$ of its maximal activity at pH 8.0 (Figure 5b). Without any stabilizer, the purified AnSHMT showed significant stability under weakly acidic and alkaline environment ( $\mathrm{pH}$ 6.5-8.5), retaining over $80 \%$ of the maximum activity over a $\mathrm{pH}$ range from 7.0 to 8.5 for $24 \mathrm{~h}$ at $4{ }^{\circ} \mathrm{C}$, and more than $70 \%$ of the maximal activity at $\mathrm{pH} 6.5$. However, the AnSHMT exhibited a rapid decrease in activity at pH 5.5 (Figure $5 \mathrm{~d}$ ).

Table 1 Steady-state kinetic parameters for the wild-type AnSHMT and the mutant

\begin{tabular}{llll}
\hline Enzyme & $\boldsymbol{K m}(\mathbf{m M})$ & $\boldsymbol{k}_{\text {cat }}\left(\mathbf{m i n}^{-1}\right)$ & $\boldsymbol{k}_{\text {cat }} / \mathbf{K m}\left(\mathbf{m i n}^{-\mathbf{1}} \mathbf{M}^{-\mathbf{1}}\right)$ \\
\hline WT & $57.86 \pm 0.07$ & $96.02 \pm 0.12$ & $1.66 \times 10^{3}$ \\
I249L & $61.95 \pm 0.13$ & $285.3 \pm 0.15$ & $4.61 \times 10^{3}$ \\
\hline
\end{tabular}

Note. The data are the average of three replicates.
The effects of different metal ions or chemical reagents on AnSHMT are presented in Table 2. The enzyme activated by $\mathrm{Mg}^{2+}, \mathrm{Ba}^{2+}$ and EDTA, but could be strongly inhibited by $\mathrm{Hg}^{2+}, \mathrm{Cu}^{2+}, \mathrm{Zn}^{2+}$ and $\mathrm{Fe}^{2+}$, and slightly inhibited by $\mathrm{Co}^{2+}, \mathrm{Mn}^{2+}, \mathrm{DTT}$, and $\mathrm{CO}\left(\mathrm{NH}_{2}\right)_{2}$. Besides, the enzyme was not significantly influenced in activity by $\mathrm{NH}_{4}^{+}, \mathrm{Sl}^{2+}, \mathrm{Ca}^{2+}, \mathrm{Pb}^{2+}, \mathrm{SDS}$ and CTAB.

\section{Discussion}

The taxonomy of the bacterium A. nicotianae (ATCC 15236) was studied in 1982 [26]. While no paper on the characterization of the SHMT from Arthrobacter was reported. The full-length of the glyA gene from A. nicotianae was obtained by DOP-PCR [13] with moderate modifications, which represents a rapid, efficient, and species-independent technique for general DNA amplification. To the best of our knowledge, this is the first report on the application of this technique to clone the $g l y A$ gene, suggesting that its potential application in the cloning of other $g l y A$ genes. The $g l y A$ encoding a novel SHMT shared $54.3 \%, 53.6 \%, 50.9 \%, 41.2 \%$, and $40.3 \%$ similarities to the known enzymes from $E$. coli, $H$. methylovorum GM2, C. jejuni, B. japonicum, and rabbit liver mitochondria, respectively.

Currently, L-serine is mainly produced through cellular or enzymatic conversion from the precursor glycine plus a $\mathrm{C}_{1}$ compound, in which SHMT is the key enzyme $[3,4]$. E. coli SHMT forms a tight homodimer similar to that of AAT and other $\alpha$-PLP enzymes, with the active site at the interface of the two monomers [5]. Directed evolution is a technique that can overcome the limitations of natural enzymes used as biocatalysts, for this technique does not only rely on a detailed understanding 

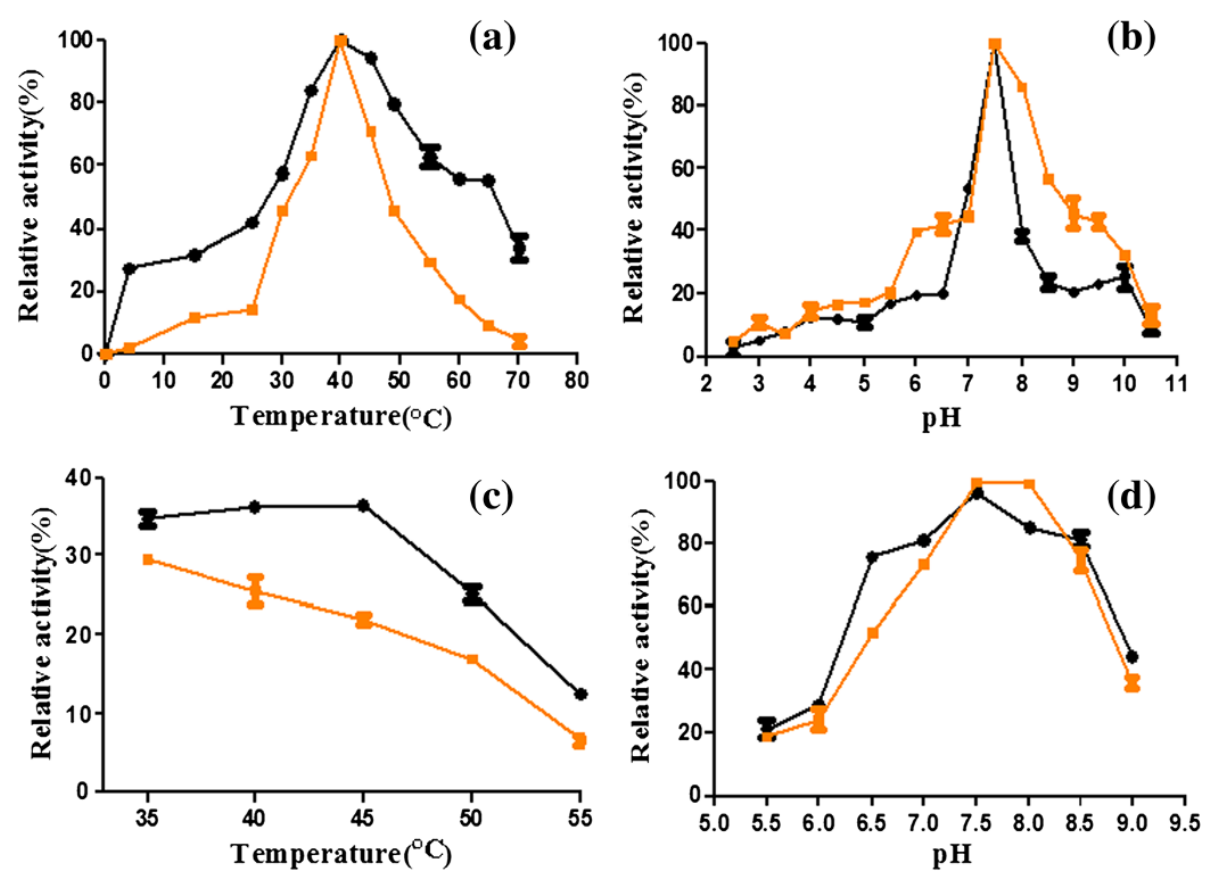

Figure 5 Effects of temperature and pH on activity. (a) Effect of temperature on the activity of the AnSHMT and the I249L-SHMT. The optimal temperature was determined by measuring the activity at temperatures from 0 to $70^{\circ} \mathrm{C}$. The maximal activity was taken as $100 \%$. (b) Effect of pH on the activity of the enzymes. The activity was measured over a pH values ranging from 2.5 to 10.5 , and the maximal activity was taken as $100 \%$. (c) Effect of temperature on the stability of the AnSHMT and the I249L-SHMT. At the optimal pH 7.5, the purified enzyme was pre-treated at a different temperature for $1 \mathrm{~h}$. The activity of the enzyme without pre-incubation was defined as $100 \%$. (d) The pH stability of the enzymes was determined by incubating the enzymes at a different $\mathrm{pH}$ at $4^{\circ} \mathrm{C}$ for $24 \mathrm{~h}$. Then assays were conducted in the standard conditions and the enzyme activity without pre-treatment was taken as 100\%. Error bars represent the standard deviation. Black circles represent the AnSHMT (•), and black squares represent the I249L-SHMT (a).

of the relationship between enzyme structure and function, but on the simple powerful Darwinian principles of mutation and selection [27]. By targeting mutations to certain amino acids, we can map the enzyme active site, investigate mechanisms, and study structure-function relationships [28]. The site-directed mutagenesis methods are usually used to generate cloned DNAs with modified sequences to examine the importance of specific residues in the protein structure and function [29]. Therefore, studying the SHMT enzymatic properties and improving the catalytic efficiency can be available for insight into the industrial production of L-serine and further research.

To the best of our knowledge, this is the first report of the characterization of the SHMT which comes from Arthrobacter. Unlike Hyphomicrobium methylovorum's SHMT $\left(37^{\circ} \mathrm{C}\right)$ [4], the AnSHMT exhibited the highest activity at $40^{\circ} \mathrm{C}$ in the assays of the enzymatic characteristics, and retained $84 \%$ and $94.2 \%$ of the maximal activity at $35^{\circ} \mathrm{C}$ and $45^{\circ} \mathrm{C}$, respectively, and less than $40 \%$ of the activity after $1 \mathrm{~h}$ pre-treatment at $35^{\circ} \mathrm{C}$ and $45^{\circ} \mathrm{C}$. Without any stabilizer, the AnSHMT displayed higher $\mathrm{pH}$ stability profiles $(\mathrm{pH} 6.5-8.5)$ than that from Hyphomicrobium methylovorum ( $\mathrm{pH} 6.0$ and 7.5) under alkaline environment. The I249L-SHMT showed nearly no loss in activity after $24 \mathrm{~h}$ incubation under $\mathrm{pH} 8.0$, while the AnSHMT retained about $85 \%$ of the maximum activity. The AnSHMT was not affected by EDTA, indicating that the metal ions were not appropriate to the enzyme. Additionally, the loss of activity of the enzyme in the presence of $\mathrm{Hg}^{2+}$ might be attributed to the interaction with thiol groups of Cys residue(s), dry residue(s), or carboxyl group (s) of amino acid(s) [30].

The replacement of isoleucine with leucine at the 249 position resulted in a 2.78 -fold increase of the catalytic efficiency $\left(k_{\text {cat }} / \mathrm{Km}\right)$ in the mutant I249L over the wide type, namely a $7 \%$ increase in $K_{\mathrm{m}}$ and a 2.97 -fold increase in $k_{\text {cat }}$ indicating that the 249 site is vital to improve the enzyme activity. The increase of the $7 \%$ for the $K_{\mathrm{m}}$ may be due to the decreased of enzyme and substrate affinity with the replacement of isoleucine by leucine at the 249 position. The results of the site-directed mutagenesis performed by the sequences alignment and bioinformatics analysis indicate that the 249 site is vital to improve the enzyme activity. The improvement of the catalytic efficiency could be attributed to four factors: (i) based on the model structures, the mutant is too far away from the substrate to participate in direct 
Table 2 Effects of metal ions and chemical reagents on the activity of purified AnSHMT ${ }^{\mathrm{a}}$

\begin{tabular}{lll}
\hline Reagents & Concentration $(\mathbf{m M}$ or \%) & Relative activity (\%) \\
\hline Control & 0 & $100 \%$ \\
$\mathrm{Hg}^{2+}$ & 1 & $-\mathrm{b}$ \\
$\mathrm{Co}^{2+}$ & 1 & $60.03 \pm 0.27 \mathrm{C}$ \\
$\mathrm{K}^{+}$ & 1 & $100.44 \pm 0.37$ \\
$\mathrm{Na}^{+}$ & 1 & $100.62 \pm 0.30$ \\
$\mathrm{NH}_{4}^{+}$ & 1 & $95.12 \pm 0.58$ \\
$\mathrm{Sl}^{2+}$ & 1 & $94.44 \pm 0.83$ \\
$\mathrm{Mg}^{2+}$ & 1 & $108.38 \pm 0.85$ \\
$\mathrm{Ca}^{2+}$ & 1 & $91.38 \pm 0.11$ \\
$\mathrm{Ba}^{2+}$ & 1 & $102.58 \pm 0.33$ \\
$\mathrm{Cu}^{2+}$ & 1 & $8.95 \pm 0.36$ \\
$\mathrm{Zn}^{2+}$ & 1 & $2.91 \pm 0.11$ \\
$\mathrm{Mn}^{2+}$ & 1 & $60.81 \pm 0.28$ \\
$\mathrm{Fe}^{2+}$ & 1 & $-\mathrm{b}$ \\
$\mathrm{Pb}^{2+}$ & 1 & $98.90 \pm 0.32$ \\
$\mathrm{CO}(\mathrm{NH})_{2}$ & 1 & $60.59 \pm 0.45$ \\
$\mathrm{DTT}$ & 1 & $59.29 \pm 0.08$ \\
$\mathrm{CTAB}$ & $0.3 \%$ & $97.05 \pm 0.04$ \\
$\mathrm{EDTA}$ & $1 \%$ & $101.25 \pm 0.65$ \\
$\mathrm{SDS}^{2+}$ & $5 \%$ & $-\mathrm{b}$ \\
\hline$:$ & 1 &
\end{tabular}

${ }^{a}$ : all assays were performed in the standard conditions and the activity measured without additional reagents and ions was taken as $100 \%$. The data are the average of three replicates; ${ }^{\text {b}}$ : unmeasured data; ${ }^{\text {c: }}$ Relative activity \pm the standard deviation.

interaction, resulting in no mutation in the catalytic active site (Figure 3), which could be due to the possibility that the occurrence of most mutations in the active site would inactivate the enzyme, because SHMT is one of the most highly conserved proteins, and the mutations likely exert their effects by changing the conformation of the active site rather than by interacting directly with substrates [2]; (ii) the three-dimensional structure (Figure 3) of AnSHMT shows that the isoleucine (249 site) is probably located at the end of an active channel and the PLP binding region at the other end of the active channel, so the change of the 249 site residue has no effect on the PLP binding progress; (iii) when PLP or other molecules bind the enzyme, the steric hindrance may be reduced by the residue and is altered by leucine; and (iv) as the relative abundance of isoleucine and leucine are 4.4 and 7.8 , respectively, more steric hindrance is produced by the binding of the substrate to the enzymatic molecules through the cavity of the former. Further exploration concerning the structure-activity relationship of SHMT is necessary owing to the limited information about the relationship [5-7] and the interesting site would be useful for these work.

\section{Conclusion}

The AnSHMT in the present study is a novel one from A. nicotianae, sharing $54.3 \%$ similarity to the known SHMT from E. coli. The enzyme showed better stability under weakly alkali conditions $(\mathrm{pH}$ 6.5-8.5) than Hyphomicrobium methylovorum's SHMT ( $\mathrm{pH} 6.0$ and 7.5), and exhibited the optimal activity at $\mathrm{pH} 7.5$ and $40^{\circ} \mathrm{C}$. Through site-directed mutagenesis, the catalytic efficiency $\left(k_{\text {cat }} / \mathrm{Km}\right)$ of the mutant I249L was 2.78 -fold higher than that of wide type. These characteristics provide useful information about the interesting site, and the application of DOP-PCR in cloning a novel $g l y A$ gene.

\section{Methods}

Reagents, bacterial strains, vectors and cultivation conditions

The restriction enzymes, T4 DNA ligase, Taq DNA polymerase, pMD18-T vectors, molecular weight marker, gel extraction kit and the DNA purification Kit used in the research were all from purchased from TaKaRa Co. (Dalian, China) and Qiagen Co. (Germany). The Pfu DNA polymerase, PreScission protease and the GST • Bind Resin were purchased from TransGen Co. (China), GE Healthcare Co. and Merck Co. (Germany), respectively. All oligonucleotide primers (Table 3) and fragments were synthesized and sequence by GenScript Co. (Nanjing, China). Unless otherwise stated, all the other chemicals used in this study arose out of analytical grade and purchased from Sinopharm Chemical Reagent (Wuhan, China).

The SHMT screening medium [31], consisting of 125 $\mathrm{ml} / \mathrm{L}$ methanol, $5 \mathrm{~g} / \mathrm{L} \mathrm{NaCl}$ and $5 \mathrm{~g} / \mathrm{L}$ glycine, was ready to detect the enzyme activity of the bacterium. A. nicotianae, with high SHMT activity used in this study, was isolated from the Nanhu-Lake (Wuhan, China) and preserved in our laboratory and was cultivated in LuriaBertani (LB) medium at $37^{\circ} \mathrm{C}$. E. coli $\mathrm{DH} 5 \mathrm{a}$ and E. coli BL21 (DE3) strains were cultured in Luria-Bertani (LB)

Table 3 Primers used for plasmid construction and the site-directed mutagenesis

\begin{tabular}{lll}
\hline Primers & $\mathbf{5}^{\prime}$ to $\mathbf{3}^{\prime}$ & $\begin{array}{l}\text { Purpose or } \\
\text { references }\end{array}$ \\
\hline DP-F & RTGAMCMCKNYATC & This study \\
DP-R & YTACCCSWGSTCSK & This study \\
An-F & CGGGATCCATGAGCAACCAGACTTTGAATC & This study \\
An-R & CGGAATTCCTACTCGGAAACCTTTGGCAGGT & This study \\
I249L-F & CCGCGTGGCGGCCTGATTCTGTCGA & This study \\
I249L-R & CAGGCCGCCACGCGGACCAGCCAAC & This study \\
\hline
\end{tabular}

IUPAC ambiguity codes: $\mathrm{M}=\mathrm{A} / \mathrm{C}, \mathrm{R}=\mathrm{A} / \mathrm{G}, \mathrm{W}=\mathrm{A} / \mathrm{T}, \mathrm{S}=\mathrm{G} / \mathrm{C}, \mathrm{Y}=\mathrm{C} / \mathrm{T}, \mathrm{K}=\mathrm{G} / \mathrm{T}$ and $\mathrm{N}=\mathrm{A} / \mathrm{G} / \mathrm{C} / \mathrm{T}$. I indicates inosine. Restriction sites BamH1 and $E c o R I$ in primers $A n-\mathrm{F} / \mathrm{R}$ and the mutated site are underlined; Start and stop codons are marked in bold; site-directed mutagenesis site is underline in I249L-F and I249L-R. 
medium containing ampicillin $(100 \mu \mathrm{g} / \mathrm{mL})$ and used as cloning and expression hosts, respectively. Plasmid pGEX6P-1 was utilized for the preparation of the mutant and the purification of $A n S H M T$ and its mutant. The submitted work does not contain any experiments using animals or humans.

\section{Gene cloning}

The full ORF of glyA from A. nicotianae was obtained by DOP-PCR using both end degenerate primers with the following program: (i) $94^{\circ} \mathrm{C}$ for $5 \mathrm{~min}$, (ii) 30 cycles of $94^{\circ} \mathrm{C}$ for $30 \mathrm{~s}, 44-48^{\circ} \mathrm{C}$ for $30 \mathrm{~s}$, and $72^{\circ} \mathrm{C}$ for $1 \mathrm{~min}$ $30 \mathrm{~s}$, and (iii) $72^{\circ} \mathrm{C}$ for $10 \mathrm{~min}, \mathrm{DP}-\mathrm{F}$ and DP-R (Table 3), which were designed according to the result of the multiple sequence alignment (Figure $4 \mathrm{a}$ and $4 \mathrm{~b}$ ) between glyA gene sequences and the genus of Arthrobacter obtained from the NCBI database. After amplification, the PCR product was purified by agarose gel electrophoresis, and was cloned into PMD18-T vector and sequenced. After that, the $g l y A$ was obtained from the chromosome DNA of $A$. nicotianae by PCR using the forward and reverse primers (An-F and An-R, Table 3) under the following conditions: 1 cycle at $94^{\circ} \mathrm{C}$ for 5 min; 30 cycles at $94^{\circ} \mathrm{C}$ for $30 \mathrm{~s}, 52^{\circ} \mathrm{C}$ for $30 \mathrm{~s}$ and $72^{\circ} \mathrm{C}$ for $1 \mathrm{~min} 30 \mathrm{~s}$; and 1 final additional cycle at $72^{\circ} \mathrm{C}$ for $10 \mathrm{~min}$. After doubledigestion with BamHI and EcoRI, the resulting PCR product was gel-purified and cloned into the BamHIEcoRI sites of pGEX-6p-1, generating pGEX-6p-AnglyA containing the glutathione-S-transferase (GST) tag. The construction accuracy was confirmed by sequencing at Nanjing GenScript Company.

\section{Site-directed mutagenesis}

The position of the site-directed mutagenesis was selected founded on the result of the multiple sequence alignment of SHMTs (Figure 2). The amino acid sequences which were reported to belong to $E$. coli, rabbit liver mitochondria, A.radioresistens, B. japonicum, C. jejuni, and $A$. nicotianae, respectively. The distinct amino acid residues close to activity site were observed and assumed to produce a negative effect on enzymatic activity [2]. As shown in Figure 2, an interesting phenomenon was detected in the site underlined and marked by a five-pointed star, indicating that it was isoleucine rather than leucine close to the sequence TSTTHKTL (Figure 2c), which was highly conserved in all known SHMT proteins $[5,14,24]$.

The site-directed mutagenesis was done by PCR using the plasmid pGEX-6p-AnglyA as the template and primers designed from pairs of complementary oligonucleotides containing the desired mutant (Table 3). The PCR mixture $(50 \mu \mathrm{l})$ was composed of a PCR buffer, $10 \mathrm{ng}$ template pGEX-6p-AnglyA, $0.2 \mu \mathrm{M}$ each oligonucleotide, $0.6 \mu \mathrm{M}$ dNTP and 1 unit of FAST Pfu DNA polymerase (TransGen, China). The PCR was performed in the following three steps: (i) $97^{\circ} \mathrm{C}$ for $2 \mathrm{~min}$; (ii) $20 \mathrm{cy}-$ cles of $95^{\circ} \mathrm{C}$ for $20 \mathrm{~s}, 54^{\circ} \mathrm{C}$ for $20 \mathrm{~s}$, and $72^{\circ} \mathrm{C}$ for $3 \mathrm{~min}$ $20 \mathrm{~s}$; and (iii) $72^{\circ} \mathrm{C}$ for $7 \mathrm{~min}$ with the I249L-F and I249L-R (Table 3). The PCR product was gel-purified, treated with DpnI to eliminate methylated ancestral template through an overnight incubation at $37^{\circ} \mathrm{C}$, and then transformed into $E$. coli DH5 $\alpha$ competent cells. The recombinant plasmids were checked by DNA sequencing, and the successfully introduced desired mutation was designated as pGEX-6p-I249L.

\section{Expression and purification of wild-type AnSHMT and mutant enzyme}

The recombinant plasmids pGEX-6p-AnglyA and pGEX6p-I249L were transformed into DE3 for the SHMT expression. DE3 strain harboring the recombinant plasmid was inoculated into LB liquid medium with ampicillin $(100 \mu \mathrm{g} / \mathrm{mL})$ and incubated at $37^{\circ} \mathrm{C}$ overnight. Subsequently, the mixture was transferred into fresh LB liquid medium (1:100 dilution) containing ampicillin $(100 \mu \mathrm{g} / \mathrm{mL})$ and cultured at $37^{\circ} \mathrm{C}$ for $3-4 \mathrm{~h}$. When the cells reached an optical density of 0.6-0.8 at $600 \mathrm{~nm}$, protein expression was induced by adding IPTG to a final concentration of $0.1 \mathrm{mM}$ and the mixture was incubated at $18^{\circ} \mathrm{C}$ for $12 \mathrm{~h}$. After that, the cells were harvested and disrupted with High Pressure Homogenizer (NS100IL 2 K, Niro Soavi, Germany). Finally, the SHMTs were purified by glutathione-S-transferase (GST) Gene Fusion System (GE Healthcare, Sweden).

\section{Measurement of SHMT activity}

Standard enzyme activity of phenylserine degradation was measured with DL-3-phenylserine as substrate as previously described by Lee and Hsiao [32] with moderate modifications. Briefly, standard enzyme activity assay was performed by adding moderate purification enzyme into the $1 \mathrm{~mL}$ reaction system at $\mathrm{pH} 7.8$ with sodium phosphate buffer containing $50 \mathrm{mM}$ DL-3-phenylserine, $50 \mu \mathrm{M}$ PLP, $1 \mathrm{mM} \mathrm{Na}{ }_{2}$ EDTA (ethylene diamine tetraacetic acid) and $25 \mathrm{mM}$ sodium sulfate. When cells were used in the reaction system, $0.03 \%(\mathrm{w} / \mathrm{v})$ cetyltrimethyl ammonium bromide (CTAB) was added. The reaction was conducted for at $30^{\circ} \mathrm{C}$, and $1 \mathrm{~h}$ later, and the production of benzaldehyde was measured by its strong absorbance at $279 \mathrm{~nm}$ [2]. One unit of SHMT activity was defined as the amount of enzyme that released $1 \mu$ mole benzaldehyde per hour (benzaldehyde as standard). Specific activity was reported in units/mg protein.

\section{Biochemical characterization of the enzyme}

The optimal $\mathrm{pH}$ of SHMT was determined at $30^{\circ} \mathrm{C}$ in different buffers at $\mathrm{pH}$ 2.5-10.5, namely $0.2 \mathrm{M} \mathrm{Na}_{2} \mathrm{HPO}_{4} /$ $0.1 \mathrm{M}$ citric acid buffer ( $\mathrm{pH}$ 2.5-8.0) and $50 \mathrm{mM}$ glycine- 
$\mathrm{NaOH}$ buffer ( $\mathrm{pH} 8.0-10.5)$. The optimum temperature for the enzyme was measured by performing the SHMT activity assay for $1 \mathrm{~h}$ at temperatures from 0 to $70^{\circ} \mathrm{C}$ under $\mathrm{pH}$ 7.5. The thermal stability of the enzyme was determined under the optimal $\mathrm{pH}$ by pre-incubating the enzyme at temperatures from $35^{\circ} \mathrm{C}$ to $55^{\circ} \mathrm{C}$ for $60 \mathrm{~min}$ and then the residual activity was measured as described above. To determine the $\mathrm{pH}$ stability of the SHMT, the recombinant SHMT was incubated at $4^{\circ} \mathrm{C}$ for $24 \mathrm{~h}$ in different buffer systems ( $\mathrm{pH}$ 5.5-9.0), and the residual activity was measured under standard assay conditions. The biochemical characterization of the I249L-SHMT was performed with the same methods.

Effects of metal ions and other chemical compounds on the enzyme activity were determined in the standard reaction system at $40^{\circ} \mathrm{C}$ for $1 \mathrm{~h}$ at $\mathrm{pH} 7.5$.

\section{Computer model generation}

The position of site-directed mutagenesis was indicated on the three-dimensional structure of AnSHMT, which was constructed from the known $\mathrm{x}$-ray structure of Burkholderia Pseudomallei Mycobacterium Tuberculosis T.Th.Hb8 (PDB entry 3H7F, 2DKJ and 3ECD) using Swiss-Model, a knowledge-based protein modeling tool [33]. Furthermore, the PLP binding region and the active site were marked on the three-dimensional structure.

\section{Competing interests}

The authors declare that they have no competing interests.

\section{Authors' contributions}

WJ: designed and supervised the experiments, have performed gene cloning, expression in E. coli, rational design, enzyme characterization and drafted this manuscript. LC: have performed gene cloning, expression in $E$. coli and revised the manuscript. $\mathrm{NH}$ : have conceived the study, designed and supervised the experiments. SHY: have performed expression in E. coli, rational design and revised the manuscript. BL: have performed threedimensional structure and revised the manuscript. ZDL: have conceived the study, designed and supervised the experiments, is a corresponding author. All authors have read and approved the manuscript.

\section{Acknowledgement}

Financial support for this work was provided by China National Natural Sciences Foundation (No. 51008012).

\section{Author details}

${ }^{1}$ State Key Laboratory of Agricultural Microbiology, College of Life Science and Technology, Huazhong Agricultural University, Wuhan 430070, P. R. China. ${ }^{2}$ College of Biotechnology and Pharmaceutical Engineering, Nanjing Tech University, Nanjing 211800, P. R. China.

Received: 13 July 2014 Accepted: 22 October 2014

Published online: 14 November 2014

\section{References}

1. Izumi Y, Yoshida T, Miyazaki SS, Mitsunaga T, Ohshiro T, Shimao M, Miyata A, Tanabe T: L-Serine production by a methylotroph and its related enzymes. Appl Microbiol Biotechnol 1993, 39(4):427-432.

2. Zuo ZY, Zheng ZL, Liu ZG, Yi QM, Zou GL: Cloning, DNA shuffling and expression of serine hydroxymethyltransferase gene from $<\mathrm{i}>$ Escherichia coli</i > strain AB90054. Enzyme Microb Technol 2007, 40(4):569-577.
3. Peters-Wendisch P, Stolz M, Etterich H, Kennerknecht N, Sahm H, Eggeling L: Metabolic engineering of Corynebacterium glutamicum for L-serine production. Appl Environ Microbiol 2005, 71(11):7139-7144.

4. Miyazaki SS, Toki S, Izumi Y, Yamada H: Purification and characterization of a serine hydroxymethyltransferase from an obligate methylotroph, Hyphomicrobium methylovorum GM2. Eur J Biochem 1987, 162(3):533-540.

5. Scarsdale JN, Radaev S, Kazanina G, Schirch V, Wright H: Crystal structure at $2.4 \AA$ resolution of E. coli serine hydroxymethyltransferase in complex with glycine substrate and 5-formyl tetrahydrofolate1. J Mol Biol 2000, 296(1):155-168.

6. Renwick SB, Snell K, Baumann U: The crystal structure of human cytosolic serine hydroxymethyltransferase: a target for cancer chemotherapy. Structure 1998, 6(9):1105-1116.

7. Scarsdale J, Kazanina G, Radaev S, Schirch V, Wright H: Crystal structure of rabbit cytosolic serine hydroxymethyltransferase at 2.8 resolution: mechanistic implications. Biochemistry 1999, 38(26):8347-8358.

8. Blakley R: The interconversion of serine and glycine: role of pteroylglutamic acid and other cofactors. Biochem J 1954, 58(3):448.

9. Jones-Mortimer M, Wheldrake J, Pasternak C: The control of sulphate reduction in Escherichia coli by O-acetyl-L-serine. Biochem J 1968, 107(1):51.

10. Ulevitch RJ, Kallen RG: Studies of the reactions of lamb liver serine hydroxymethylase with L-phenylalanine: kinetic isotope effects upon quinonoid intermediate formation. Biochemistry 1977, 16(24):5350-5354.

11. Rao DN, Rao NA: Purification and regulatory properties of mung bean (Vigna radiata L.) serine hydroxymethyltransferase. Plant Physiol 1982, 69(1):11.

12. Barra D, Martini F, Angelaccio S, Bossa F, Gavilanes F, Peterson D, Bullis B, Schirch L: Sequence homology between prokaryotic and eukaryotic forms of serine hydroxymethyltransferase. Biochem Biophys Res Commun 1983, 116(3):1007-1012.

13. Telenius H, Carter NP, Bebb CE, Ponder BA, Tunnacliffe A: Degenerate oligonucleotide-primed PCR: general amplification of target DNA by a single degenerate primer. Genomics 1992, 13(3):718-725.

14. Garrow TA, Brenner A, Whitehead V, Chen X-N, Duncan R, Korenberg J, Shane B: Cloning of human cDNAs encoding mitochondrial and cytosolic serine hydroxymethyltransferases and chromosomal localization. J Biol Chem 1993, 268(16):11910-11916.

15. Byrne PC, Sanders P, Snell K: Nucleotide sequence and expression of a CDNA encoding rabbit liver cytosolic serine hydroxymethyltransferase. Biochem J 1992, 286(Pt 1):117-123.

16. Miyata A, Yoshida T, Yamaguchi K, Yokoyama C, Tanabe T, Toh H, Mitsunaga T, Izumi Y: Molecular cloning and expression of the gene for serine hydroxymethyltransferase from an obligate methylotroph Hyphomicrobium methylovorum GM2. Eur J Biochem 1993, 212(3):745-750.

17. Schirch V, Hopkins S, Villar E, Angelaccio S: Serine hydroxymethyltransferase from Escherichia coli: purification and properties. J Bacteriol 1985, 163(1):1-7.

18. Vidal L, Calveras J, Clapes P, Ferrer P, Caminal G: Recombinant production of serine hydroxymethyl transferase from Streptococcus thermophilus and its preliminary evaluation as a biocatalyst. Appl Microbiol Biotechnol 2005, 68(4):489-497.

19. Hamilton BK, Hsiao H-Y, Swann WE, Anderson DM, Delente JJ: Manufacture of L-amino acids with bioreactors. Trends Biotechnol 1985, 3(3):64-68.

20. Parikh MR, Matsumura I: Site-saturation mutagenesis is more efficient than DNA shuffling for the directed evolution of $\beta$-fucosidase from $\beta$ galactosidase. J Mol Biol 2005, 352(3):621-628.

21. Wilks HM, Hart KW, Feeney R, Dunn CR, Muirhead H, Chia WN, Barstow DA Atkinson T, Clarke AR, Holbrook JJ: A specific, highly active malate dehydrogenase by redesign of a lactate dehydrogenase framework. Science 1988, 242(4885):1541-1544.

22. Chen $R$, Greer A, Dean AM: Redesigning secondary structure to invert coenzyme specificity in isopropylmalate dehydrogenase. Proc Natl Acad Sci U S A 1996, 93(22):12171-12176.

23. Vick JE, Schmidt DM, Gerlt JA: Evolutionary potential of ( $\beta / \alpha)$ 8-barrels: in vitro enhancement of a "new" reaction in the enolase superfamily. Biochemistry 2005, 44(35):11722-11729.

24. Usha R, Savithri HS, Appaji Rao N: The primary structure of sheep liver cytosolic serine hydroxymethyltransferase and an analysis of the evolutionary relationships among serine hydroxymethyltransferases. Biochim Biophys Acta 1994, 1204(1):75-83. 
25. Hong MC, Wu ML, Chang MC: Cloning and complete nucleotide sequence of Acinetobacter radioresistens CMC-1 AglyA gene encoding serine hydroxymethyltransferase. FEMS Microbiol Lett 1999, 170(2):413-418.

26. Stackebrandt E, Fowler V, Fiedler F, Seiler H: Taxonomic Studies on Arthrobacter nicotianae and Related Taxa: Description of Arthrobacter uratoxydans sp. nov. and Arthrobacter sulfureus sp. nov. and Reclassification of Brevibacterium protophormiae as Arthrobacter protophormiae comb. nov. Syst Appl Microbiol 1982, 4(4):470-486.

27. Zhang Z-G, Yi Z-L, Pei X-Q, Wu Z-L: Improving the thermostability of $\langle i>$ Geobacillus stearothermophilus $</ \mathrm{i}>$ xylanase XT6 by directed evolution and site-directed mutagenesis. Bioresour Technol 2010, 101(23):9272-9278

28. Georgescu R, Bandara G, Sun L: Saturation Mutagenesis. In Directed Evolution Library Creation. Berlin: Springer; 2003:75-83.

29. Liu H, Naismith JH: An efficient one-step site-directed deletion, insertion, single and multiple-site plasmid mutagenesis protocol. BMC Biotechnol 2008, 8(1):91.

30. McGavin M, Forsberg C, Crosby B, Bell A, Dignard D, Thomas D: Structure of the cel-3 gene from Fibrobacter succinogenes $\mathrm{S} 85$ and characteristics of the encoded gene product, endoglucanase 3. J Bacteriol 1989, 171 (10):5587-5595.

31. Patt $\mathrm{T}$, Cole $\mathrm{G}$, Hanson R: Methylobacterium, a new genus of facultatively methylotrophic bacteria. Int J Syst Evol Microbiol 1976, 26(2):226.

32. Lee TK, Hsiao H-y: Synthesis of I-tyrosine by a coupled reaction of serine hydroxymethyltransferase and $\beta$-tyrosinase. Enzyme Microb Technol 1986 8(9):523-526.

33. Peitsch M: Protein modeling by E-mail. Bio/Technol 1995, 13:658-660

doi:10.1186/s12896-014-0093-9

Cite this article as: Jiang et al:: A novel serine hydroxymethyltransferase from Arthrobacter nicotianae: characterization and improving catalytic efficiency by rational design. BMC Biotechnology 2014 14:93.

\section{Submit your next manuscript to BioMed Central and take full advantage of:}

- Convenient online submission

- Thorough peer review

- No space constraints or color figure charges

- Immediate publication on acceptance

- Inclusion in PubMed, CAS, Scopus and Google Scholar

- Research which is freely available for redistribution 